\title{
METHODS OF CHALLENGING SEARCHES AND SEIZURES IN CALIFORNIA
}

Sergeant Grennan and Officer Hanks were in possession of a warrant authorizing them to search Miss Peterson's house and car. However, they searched another car that Miss Peterson was driving, not the car named in the search warrant, and justified this conduct on the ground that she engaged in evasive actions with the car. Officer Hanks and two others then searched the house under the warrant. Both searches turned up heroin and Miss Peterson was booked for possession of narcotics. How can her attorney challenge the legality of the searches?

The facts surrounding the seizure are those of a recent California case, ${ }^{1}$ and are representative of a typical narcotics search and seizure. In the actual case there was a question of probable cause for the issuance of the warrant and for the search of the wrong car without a warrant, but the majority opinion did not consider this issue. The court limited itself to the question of the procedural devices available for challenging the legality of a search.

The scope of this Comment is similarly limited to procedural devices for challenging searches and seizures. Its purpose is to explore the procedural methods presently available in Cahifornia and to suggest some inprovements in the law. A bill that changes the present law has recently come before the Califorma Legislature, and the merits and disadvantages of this proposal will be explored. Finally, a draft statute will be proposed that will perhaps be of assistance to the Legislature when it examines this problem in the near future.

THE PRESENT CALIFORNIA LAW

People v. Cahan ${ }^{2}$ held that evidence obtained by an illegal search and seizure is inadmissible in a criminal proceeding. ${ }^{3}$ To avoid waiving his claim that a search and seizure was illegal, a defendant must know how and when he may raise this issue. The accused's opportunity to challenge the legality of a search and seizure differs according to whether the prosecution has been begun by information or by indictment.

\section{A. The Accusatory Pleading System ${ }^{4}$}

In Califorma there are two ways to initiate a prosecution-by infor-

1 People v. Peterson, 233 Cal. App. 2d 481, 43 Cal. Rptr. 457 (1965).

244 Cal. 2d 434, 282 P.2d 905 (1955).

3 The exclusionary rule now applies to all the states. Mapp v. Ohio, 367 U.S. 643 (1961).

4 The following material on the accusatory pleading system is taken largely from an interview with Mr. Jolın Nunes, Alameda County Public Defender, Oct. 22, 1965 [hereinafter cited as Nunes Interview, Oct. 22, 1965]. Penal Code sections will be noted where relevant. 
mation or by indictment. ${ }^{5}$ If the prosecution is by information, the first step is the filing of a complaint by the district attorney. ${ }^{6}$ Then, if the accused is in custody-and he usually is-the magistrate in either the justice or municipal court will give him a copy of the complaint and inform him of the charge against him and of his right to counsel. ${ }^{7}$

When the accused has obtained counsel, the magistrate will take his plea. ${ }^{8}$ If he pleads guilty, the case will be certified to the superior court where he will be sentenced..$^{9}$ If he pleads not guilty, a preliminary examination will be scheduled in the mumcipal or justice court to inquire whether there is sufficient cause to hold him for trial. ${ }^{10}$ If the magistrate concludes that there is reasonable cause, he will order the accused held to answer in the superior court. ${ }^{11}$ The district attorney will file the information and the case will go up to the superior court where the accused will be arraigned and his plea taken. ${ }^{12}$ Then the case will go up to trial.

If the prosecution is by indictment, ${ }^{13}$ the preliminary steps in the municipal or justice court are avoided. When the grand jury returns an indictment against a person, his first court appearance is at his arraignment in the superior court. ${ }^{14}$

\section{B. Challenging a Search and Seizure Before the Trial}

\section{The Preliminary Motion to Suppress}

If the prosecution is by information, the defendant's first available method to attack a search and seizure is a motion to suppress the evidence

5 The discussion will be limited to felony cases since most cases of search and seizure occur in felony arrests. In addition, the procedure in a misdemeanor case is not materially different from that followed in a felony case begun by indictment. Interview with $\mathrm{Mr}$. Jolin Nunes, Alameda County Public Defender, Nov. 29, 1965 [lereinafter cited as Nunes Interview, Nov. 29, 1965].

6 See Car. Pen. Code \$ 806.

7 See CAL. PEN. CoDE \$ 859. Most judges refuse to take a.plea from the accused until he is represented by counsel. If he does not have counsel, the judge will usually grant a two-day continuance to allow him to obtain a private counsel or the public defender. Nunes Interview, Oct. 22, 1965.

8 See Cal. Pen. Code $\$ \S 859 a, 860$.

9 See Cal. Pen. Code $\S 859$ a.

10 See Car. Pen. Code $\$ 860$.

11 See Car. Pen. Code $\$ 872$.

12 See CaL. Pen. Code $\$ \$ 987,988$.

13 See Car. Pen. Code $\$ 917$.

14 Which method, information or indictment, a particular district attorney will use depends on many practical considerations. Among these are the number of deputies available to prosecute a case through the lower courts, and the past record of a lower court judge in sustaining a complaint or of the grand jury in returning an indictment. For example, in Alameda County the district attorney rarely uses the indictment procedure, whereas in San Francisco twenty to twenty-five per cent of prosecutions are initiated by mdictment. Interview with Mr. Al Hederman, Alameda County District Attorney Office, Oct. 29, 1965 [hereinafter cited as Eederman Interview, Oct. 29, 1965]. 
obtained. This motion is available whether the search was with or without a warrant. However, even though such a motion is available, most attorneys prefer to wait until the prehminary examination to object to the evidence. ${ }^{15}$ The preliminary motion to suppress is optional, and failure to make the motion will not prevent the defendant from objecting at trial to the introduction of the same evidence. ${ }^{16}$

One distinct advantage of the prehiminary motion to suppress is that if the motion is granted, the prosecution cannot appeal. ${ }^{17}$ If there is not enough competent evidence to hold the defendant to answer in the superior court, the prosecution will be dismissed.

\section{The Motion to Quash a Search Warrant and to Return Property}

If the search was with a warrant, the defendant has a special procedure available to him under Penal Code sections 1539 and 1540 to challenge the search and seizure. ${ }^{18}$ Although the sections are specifically concerned

15 Interview With Mr. Claude Perasso, San Francisco Public Defender Office, Oct. 29, 1965 [lereinafter cited as Perasso Interview, Oct. 29, 1965]. Alarcon, Search and Seizure Problems, in Continutng Education of the Bar, Caltrorma Crdmenal Law Practice 179, 190 (1964). The defendant may raise the issue of the legality of the search and seizure for the first time by objecting to the admission of the evidence at the preliminary examination. Badillo v. Superior Court, 46 Cal. 2d 269, 294 P.2d 23 (1956).

16 People v. Berger, 44 Cal. 2d 459, 282 P.2d 509 (1955). People v. Gershenliorn, 225 Cal. App. 2d 122, 124, 37 Cal. Rptr. 176, 177 (1964). In Berger, Justice Traynor traced the history of the motion to suppress in the federal law and concluded that recently the federal courts have permitted the trial court to entertain the motion for the first time at trial. He felt that the motion to suppress is best used at trial and not in a preliminary proceeding since a ruling on the motion at trial would be no more difficult than a ruling on any other questions of the admissibility of evidence, while a preliminary motion would inevitably result in delaying the trial. Id. at 463-64, 292 P.2d at 511-12. See also Note, 44 Car.r. L. REv. 164 (1956), which contains a good summary of the arguments for a strict rule requiring a motion to be made prior to trial. Among those enumerated are the following: The issue of legality may be decided without a jury hearing any embarrassing facts leading up to the search and seizure; difficult legal questions may be lieard in the detached atmosplere of an independent proceeding; and, the defendant may dispose of the matter without the expense or notoriety of a trial. Id. at 165-66.

17 People v. Justice Court, 185 Cal. App. 2d 256, 8 Cal. Rptr. 176 (1960). The court lield that a ruling on a preliminary motion to suppress is not appealable by the defendant because it is considered incidental to the criminal case and not an independent proceeding. A review of the judge's action will be available only if the defendant renews lis objection at trial and appeals froin a conviction. The prosecution cannot appeal from an order granting the defendant's motion because the right of the People to appeal is governed in all cases by California Penal Code $\$ 1466$ which does not authorize an appeal from an adverse ruling on a preliminary motion to suppress. Further, a writ of mandate will not issue to correct an abuse of judicial discretion in this area or to compel a judge to admit evidence. Id. at 259, 8 Cal. Rptr. at 178. See also People v. Williams, 218 Cal. App. 2d 86, 32 Cal. Rptr. 277 (1963).

18 Section 1539: "If the grounds on which the warrant was issued be controverted, [the magistrate] ... . must proceed to take testimony in relation thereto, and the testimony of each witness be reduced to writing and authenticated in the manner prescribed in section 869." 
only with return of seized property; and not with suppression of evidence, the defendant must follow the procedure outlined in the sections or he waives the right to challenge the trnth of the facts in the affidavit upon which the warrant was issued..$^{19}$

The normal procedure under sections 1539 and 1540 is to attack the search warrant before the magistrate who issued it. Many judges, however, will hold a section 1539 proceeding at the time of the preliminary examination even though they did not issue the warrant. ${ }^{20}$

The sections do not require that the motion be made at any particular time, and the rule appears to be that it may be made at any reasonable time before the trial. ${ }^{21}$

Section 1540: "If it appears that the property taken is not the same as that described in the warrant, or that there is no probable cause for believing the existence of the grounds on which the warrant was issued, the magistrate must cause it to be restored to the person from whom it was taken." If the defendant makes a motion to quash the search warrant for lack of probable cause, the motion is considered to be broad enough to include the grounds for relief in $\S 1539$ and 1540. People v. Keener, 55 Cal. 2d 714, 12 Cal. Rptr. 859, 361 P.2d 587 (1961). If the motion is granted, the property will be returned. If the property is contraband, however, and therefore not returnable as is clearly suggested in Aday v. Superior Court, 55 Cal. 2d 789, 13 Cal. Rptr. 415, 362 P.2d 47 (1961), the warrant may still be quashed since the motion to quash is severable from the motion to return property. Dunn v. Municipal Court, 220 Cal. App. 2d 858, 34 Cal. Rptr. 251 (1963). If the defendant has a $\$ 1539$ proceeding he must specifically attempt to controvert the facts behind the affidavit at that proceeding or else he waives that right. Dunn v. Municipal Court, supra. If the defendant does raise this issue and his motion is denied, he may raise the same issue again at the prehminary examination or at trial. People v. Keener, supra.

10 People v. Prieto, 191 Cal. App. 2d 62, 12 Cal. Rptr. 577 (1961); Arata v. Superior Court, 153 Cal. App. 2d 767, 315 P.2d 473 (1957). In Prieto, the court noted that in a sense $\S 1539$ is an anomaly where a defendant denies he ever possessed the property. In such a case, if he can establish that there was no probable cause for the warrant, the magistrate must cause the property to be returned to him. But the court concluded that this interpretation is well established and it would only confuse matters to change it. $I d$. at 67,12 Cal. Rptr. at 580.

20 Nunes Interview, Oct. 22, 1965. In People v. Peterson, 233 Cal. App. 2d 481, 43 Cal. Rptr. 457 (1965), the court suggested that if at the time of the preliminary examination the judge found that the defendant had not yet proceeded under $\$ \S 1539$ and 1540 , he might require the defendant to expressly waive his right to such a hearing, grant a continuance of the preliminary examination to allow the defendant time to pursue a $\S 1539$ hearing, or hold the hearing himself with the defendant's consent. Id. at 495-96, $43 \mathrm{Cal}$. Rptr. at 465-66. The latter choice would particularly be preferable where the judge who issued the warrant is no longer available to conduct a $\S 1539$ hearing. Mr. Hederman pointed out that the defendant might prefer to have the motion heard by a different judge than the one who issued the warrant since it is unlikely that the judge who issued the warrant in the first place will overrule his own decision. Hederman Interview Oct. $_{20}$ 29, 1965.

21 In People v. Keener, 55 Cal. 2d 714, 12 Cal. Rptr. 859, 361 P.2d 587 (1961), the court said that a defendant must proceed under $\S \S 1539$ and 1540 or else he cannot controvert the facts upon which the warrant was issued at a preliminary hearing, a Penal Code $\S 995$ hearing, or at trial. $I d$. at $719,12 \mathrm{Cal}$. Rptr. at 861,361 P.2d at 589. The logical reading of this language would indicate that the notion must be made before the preliminary examination. But the district court of appeal in People v. Peterson, 233 Cal. App. 2d 481, 43 Cal. Rptr. 457 (1965) placed a different interpretation on this language. In that case 
If a motion to quash made under these sections is denied, the ruling is not final and may not be appealed. However, the defendant may seek a writ of prohibition or mandate to obtain relief from the ruling. Even if he chooses not to apply for such a writ, he is not barred from raising the issue again at the preliminary examination or at trial. ${ }^{22}$ If the defendant's preliminary motion is granted, the order can probably be appealed by the State as a final judgment in a special proceeding. ${ }^{23}$

In the past the proceeding outlined in sections 1539 and 1540 was not used frequently by defense attorneys, and consequently many defendants waived their rights to controvert the truth of the facts in the affidavit. ${ }^{24}$ Recently, lowever, the proceeding has been increasing in popularity, probably because search warrants are now being more widely used. ${ }^{25}$

the defendant made several attempts to challenge the grounds upon which the warrant was issued. The first attempt was at the preliminary examination, but the judge refused to allow the defendant to make the motion on the ground that the place to attack a search warrant for a defect not apparent on its face is in a $\$ 1539$ hearing before the municipal court judge who issued it. The court in Peterson said that this was erroneous and that the judge should either have granted a continuance of the preliminary examination so that the defendant could pursue the $\S 1539$ remedy, or else have held the $\S 1539$ hearing himself with the consent of the defendant. Having been prevented from raising the issue at the preliminary examination, the defendant requested a $\$ 1539$ hearing. The hearing was scheduled by the judge but was opposed by the State on the ground that the Keener case established that the defendant must use the $\$ 1539$ proceeding before the preliminary examination. The judge accepted this contention and called off the hearing. The district court of appeal, however, refused to accept the Keener statement as applicable. They said that the statenient in Keener was made with regard to the question whether an adverse ruling under $\S 1539$ is conclusive against a defendant, and not to when the $\S 1539$ proceeding must be sought in all instances. Id. at $490,43 \mathrm{Cal}$. Rptr. at 462 . The proper rule, said the court, is that the motion must be made at a reasonable time before the trial, but not necessarily before the preliminary examination. Id. at 496, 43 Cal. Rptr. at 466.

22 People v. Keener, supra note 21. See also Dunn v. Municipal Court, 220 Cal. App. 2d 858, 34 Cal. Rptr. 251 (1963). The court in Dunn stated that $\S 1466$ of the Penal Code does not authorize an appeal from an order under $\$ \S 1539$ and 1540 or from an order denying a motion to quash. But the defendant may seek a writ of mandate directing the municipal court to quash the warrant. If the appellate department of the superior court denies the writ, the defendant may appeal under California Code of Civil Procedure \& 963 (appeal from a final judgment in a special proceeding). Id. at 863 n.1, 34 Cal. Rptr. at 255 n.1.

233 Witrin, Caimornia Procedure 2158 (1954).

24 Nunes Interview, Oct. 22, 1965.

25 This is due in large part to the rule concerning the disclosure of an informant's identity announced in the case of Pcople v. Keener, 55 Cal. 2d 714, 12 Cal. Rptr. 859, 361 P.2d 587 (1961). Keener himited the former rule of Priestly v. Superior Court, 50 Cal. 2d 812, 330 P.2d 39 (1958), which required disclosure of an informant's identity. The court in Keener held that when the" search is with a warrant the defendant is already substantially protected by the requirement that a warrant be issued only upon probable cause. If the warrant is valid on its face, the defendant may not require the disclosure of an informant's identity unless the informant is "a material witness with respect to facts directly relating to the defendant's guilt." People v. Keener, supra at 724, 12 Cal. Rptr. at 864, 361 P.2d at 592. In its last general session the Cahifornia Legislature overturned the Priestly rule for narcotics cases. The new law provides that even though there is no warrant the identity 
If there was no search warrant the defendant may still make a motion to return the property seized, although not under sections 1539 and 1540 . Such a motion is similar to a section 1539 motion, but is considered a separate proceeding from the criminal trial. A judgment granting or denying a motion to return property seized without a warrant is not reviewable on appeal from a conviction. There is no appeal from an order denying the motion, and the defendant may obtain discretionary review by writ of mandate. ${ }^{26} \mathrm{He}$ may also institute a civil action for the recovery of the property. ${ }^{27}$

of a confidential reliable informant in narcotics cases does not have to be disclosed unless the informant is a material witness. Cal. Stats. 1965 , ch. 937 , at 2549 . What effect this new law might have on the number of search warrants obtained cannot be ascertained at present.

Another reason for the popularity of the search warrant is that when there is a search warrant, the presumption is that the search is legal and the burden to establish illegahty is on the defendant. People v. Farrara, 46 Cal. 2d 265, 294 P.2d 21 (1956); People v. Acosta, 142 Cal. App. 2d 59, 298 P.2d 29 (1956). Where the search is made without a warrant, and is not incident to a lawful arrest, the burden of proof is on the prosecution to establish the reasonableness of the search. People v. King, 60 Cal. 2d 308, 32 Cal. Rptr. 825, 384 P.2d 153 (1963); People v. Molarius, 213 Cal. App. 2d 10, 28 Cal. Rptr. 541 (1963). The burden of proof is also on the prosecution if there is no warrant and the prosecution seelss to justify the search by proving that the defendant consented to it. People v. Gorg, 45 Cal. 2d 776, 291 P.2d 469 (1955).

20 People v. Gershenhorn, 225 Cal. App. 2d 122, 37 Cal. Rptr. 176 (1964).

27 Reynolds v. Roll, 122 Cal. App. 2d 826, 266 P.2d 222, cert. denied, 348 U.S. 832 (1954); Atlas Fin. Corp. v. Kenny, 68 Cal. App. 2d 504, 157 P.2d 401 (1945). Such a suit might raise the question of whether the collateral estoppel doctrine could be apphed. The collateral estoppel principle was applied to situations involving civil and criminal actions in Teitelbaum Furs Inc. v. Dominion Insurance Co., $58 \mathrm{Cal}$. 2d 601, 25 Cal. Rptr. 559, 375 P.2d 439 (1962), cert. denied, 372 U.S. 966 (1963), and Newman v. Larsen, 225 Cal. App. 2d 22, 36 Cal. Rptr. 883 (1964). As regards search and seizure issues the two instances where the problem might arise are where the defendant first institutes a civil action to recover the property, loses the suit, and is then prosecuted on a criminal charge, and where the defendant is first prosecuted on a criminal charge, and the search is held to be legal but the defendant is acquitted and proceeds to institute a civil suit for the return of the property. Both Teitelbaum and Newman involved situations where the criminal prosecution had come first and was followed by a civil action with the criminal defendant as a party. In Teitelbaum the court felt that the defendant is actually better off when the rule is applied to a civil action which was preceded by a criminal action than when it is apphed to a civil action preceded by another civil action since in the former case the standard of proof in the original action is higher. Teitelbaum did not discuss the situation where a civil suit was followed by a criminal prosecution. Cases subsequent to Teitelbaum and Nereman have also all involved criminal actions followed by civil actions. For example, see Beauregard v. Wingard, 237 A.C.A. 890, 47 Cal. Rptr. 279 (1965); Chohen v. Farmers \& Merchants Bank, 231 Cal. App. 2d 538, 41 Cal. Rptr. 888 (1964). In an early case, People v. Kovacevich, 19 Cal. App. 2d 335, 65 P.2d 807 (1937), there was a civil paternity suit against the defendant, and then he was prosecuted in a criminal action. The State claimed he was collaterally estopped from relitigating the issue of paternity. The court held otherwise since the requirement of mutuality was not met-the state liad not been a party to the first suit -and since the paternity issue had not been finally determined in the first suit. But the court's reasoning in the case would suggest that if the requirement of mutuality had been met, and if the issue had been finally determined, the doctrine of collateral estoppel would 


\section{The Motion to Set Aside the Accusatory Pleading}

At the time of his arraignment in the superior court the accused may move under Penal Code section 995 to set aside the indictment or information. ${ }^{28}$ His ground for making this motion is that he was indicted or held to answer without probable cause because the accusatory pleading is based entirely upon evidence obtained by an illegal search and seizure..$^{20}$ If as a matter of law the evidence was illegally obtained, the court must grant the motion. ${ }^{30}$ The defendant waives the right to attack the suffciency of the accusatory pleading if he does not make the section 995 motion. ${ }^{31}$

If the motion to set aside the accusatory pleading is granted, the prosecution may appeal the order. ${ }^{32}$ If the motion is denied, the defendant may petition for a writ of prohibition preventing the trial. ${ }^{33}$ If the defendant was committed or mdicted entirely upon incompetent evidence, he has been held or indicted without probable cause; and a writ of prohibition will issue. ${ }^{34}$

The dismissal of an information or indictment will not bar a trial based on a subsequent accusatory pleading clarging the same offense, ${ }^{86}$

apply where a civil suit was followed by a criminal prosecution. In the case under consideration-a civil and criminal action involving the issue of the legality of a search and seizure-the strict requirement of mutuality would be met. More importantly, it must be remembered that the issue of the legality of a search and seizure is incidental to the criminal prosecution, People v. Justice Court, 185 Cal. App. 2d 256, 8 Cal. Rptr. 176 (1960), and does not bear directly on the defendant's guilt. It is a question of law to be determined by the judge, People v. Gorg, 45 Cal. 2d 776, 291 P.2d 469 (1955), and the criminal standard of proof would not seem to be apphicable. Consequently, if the requirements of the collateral estoppel doctrine can be met, namely: (1) The issue decided in the prior adjudication must be identical with the one presented in the action in question; (2) there must have been a final judgment on the merits in the prior adjudication; and (3) the party against whom the plea is asserted must have been a party or in privity with a party to the prior adjudication, Bernhard v. Bank of America, 19 Cal. 2d 807, 813, 122 P.2d 892, 895 (1942), the collateral estoppel doctrine would seem to apply.

28 Cac. Pen. Code \& 995.

29 Rogers v. Superior Court, 46 Cal. 2d 3, 291 P.2d 929 (1955).

80 Badillo v. Superior Court, 46 Cal. 2d 269, 294 P.2d 23 (1956). The court said that if the evidence is in conflict or susceptible of conflicting inferences, or consists only of the testimony of prosecution witnesses, the court may not set aside the pleading as long as there is any substantial evidence or applicable presumption to support the conclusion that the search was legal. Id. at 272, 294 P.2d at 25.

31 Cat. Pen. Code $\$ 996$.

32 Cal. Pes. Code \& 1238.

83 Cax. Pen. Code $\$ 999 a$.

84 Badillo v. Superior Court, 46 Cal, 2d 269, 294 P.2d 23 (1956); Rogers v. Superior Court, 46 Cal. 2d 3, 291 P.2d 929 (1955). To hold a defendant to answer, the evidence does not have to be strong enough to convict him. Penal Code $\$ 872$ requires only that there be reasonable or probable cause for believing that the defendant is guilty. See Robinson v. Superior Court, 49 Cal. 2d 186, 188, 316 P.2d 1, 3 (1957).

85 People v. Prewitt, 52 Cal. 2d 330, 341 P.2d 1 (1959). 
and under Penal Code section 999 the decision in the first case that the evidence was inadmissible is not res judicata in the proceedings under the new accusatory pleading. ${ }^{36}$

\section{Challenging the Search and Seizure at Trial and On Appeal}

At trial the defendant'may object to the admission of illegally seized evidence whether or not he has objected to that evidence before. ${ }^{37}$ The denial of a pretrial motion is not conclusive; apparently the trial judge must rule on the merits of an objection made at the trial. ${ }^{38}$ If the trial court sustains the defendant's objection to the admission of the evidence, the prosecution may not appeal. Nor will a writ of mandate issue to compel the judge to admit or exclude the evidence. ${ }^{39}$

If the defendant has adequately raised the issue of the legality of a search and seizure in the lower courts, he may raise it again on an appeal from a conviction. Just how much he must do in the lower courts to preserve the issue for appeal is unclear, but it is established that he may not raise the issue for the first time on appeal. ${ }^{40}$ At present, however, a

30 People v. Van Eyk, 56 Cal. 2d 471, 15 Cal. Rptr. 150, 364 P.2d 326 (1961), cert. denied, 369 U.S. 825 (1962).

37 People v. Berger, 44 Cal. 2d 459, 282 P.2d 509 (1955). This is the optional rule previously mentioned. See note 16 supra. If there is a warrant the defendant may not object on the ground of a defect not apparent on the face of the warrant unless he has previously made that motion at a $\$ 1539$ proceeding. See note 19 supra and accompanying text.

38 People v, Carter, 48 Cal. 2d 737, 747, 312 P.2d 665, 670-71 (1957).

30 People v. Superior Court, 137 Cal. App. 2d 194, 289 P.2d 813 (1955).

40 People v. Sylvia, 54 Cal. 2d 115, 4 Cal. Rptr. 509, 351 P.2d 781 (1960); People v. Richardson, 51 Cal. 2d 445, 334 P.2d 573 (1959). It is probably the case that the defendant may preserve the issue of the truth of the facts behind the affidavit raised in a $\$ 1539$ proceeding by raising that issue again at every stage of the proceedings against him. People v. Perez, 189 Cal. App. 2d 526, 11 Cal. Rptr. 456 (1961). The court does not indicate how much less the defendant can do and still preserve the issue for appeal. But in Perez even if the defendant had not used the $\S 1539$ proceeding, he could have raised the issue of probable cause for the search on appeal because he was attacking the sufficiency of the affidavit on its face and not the facts behind the affidavit. See People v. Tillman, 238 A.C.A. 155, 158, 47 Cal. Rptr. 614, 616 (1965); Arata v. Superior Court, 153 Cal. App. 2d 767, 770, 315 P.2d 473, 476 (1957). The court in People v. Sylvia, supra at 123, 4 Cal. Rptr. at 515, 351 P.2d at 787, said that the defendant could not raise the issue for the first time on appeal if he did not raise it in the trial court. This language leaves open the possibility that the issue could be raised on appeal even if there was no objection at trial if the defendant had made a preliminary motion since the issue would not then be being raised for the first time on appeal. At present, however, it is unclear just what steps the defendant must take, if any, to preserve the issue for appeal after making a preliminary motion. The cases seem to indicate that the defendant must either object to evidence at the trial or make a motion to strike at trial or else the point will not be considered on appeal no matter what he has done before in the way of raising the issue. People v. Justice Court, 185 Cal. App. 2d 256, 8 Cal. Rptr. 176 (1960), seems to say that in the case of a preliminary motion to suppress the defendant must renew his objection at trial to preserve the issue for appeal. The court in People v. Brittain, 149 Cal. App. 2d 201, 308 P.2d 38 (1957) said that "[W]e are satisfied that unless an accused 
judgment of conviction will be reversed only if the admission of the evidence has effected a miscarriage of justice. ${ }^{41}$

\section{The Present Law in Practice}

Most cases never go to trial, and the present methods for challenging searches and seizures can be used as an effective bargaining tool..$^{42}$ Usually it is fairly obvious from the beginning whether a case is worth trying. In fact, most cases will not be worth trying, and for these defense attorneys usually prefer to play a waiting game. Of course, the receptiveness of the district attorney to any deal will depend on many practical considerations such as how burdened he is, how crowded the court calendar is, and how strong the case is against the defendant. Many times, especially in narcotics cases, the defendant will have a prior record. Some district attorneys will prepare a light charge in the original complaint, or not mention the prior convictions, in order to try to get the defendant to plead guilty. Once he pleads not guilty, however, the district attorney might amend and increase the charge or mention the priors. Motions at the time of the prehminary examination; or at the arraignment in superior court, or under sections 1539 and 1540 can be used to some degree as a bargaining lever. They consume time, and they also help the defendant to discover or expose any weaknesses in a case. ${ }^{43}$

raises the issue of a claimed unlawful search and seizure at the trial by appropriate objection or motion to strike, the point will not be considered on appeal." Id. at 203, 308 P.2d at 40 . However, apparently there had been no preliminary motion made in that case. The author in Note, 44 CALIF. L. REv. 164 (1956) says that the failure "to either make the pretrial motion or to object at the trial should waive the right to raise the issue for the first time on . . . appeal." Id. at 167. He is worried about the situation where the defendant would let the evidence go by at trial without objection, and then if convicted appeal the case on this point. Although the author uses the words "pre-trial motion or ... object at the trial," his reasoning would appear to require the motion to be made at trial.

In any case the best rule is to object at trial to the admission of the evidence, and this is almost invariably done to ensure that the question is preserved for appeal. Some objection at trial would probably be necessary where the prosecution is by information since ordinarily the transcript from the preliminary examination will not go up on appeal unless an issue in it is raised at trial. Nunes Interview, Nov. 29, 1965.

41 CAx. Const. art. VI, § 4ז̊/2; People v. Valenti, 49 Cal. 2d 199, 316 P.2d 633 (1957); People v. Tarantino, 45 Cal. 2d 590, 290 P.2d 505 (1955). However, Falyy v. Connecticut, 375 U.S. 85 (1963), casts doubt on this standard in the light of Mapp v. Ohio, 367 U.S. 643 (1961). See note 3 supra. The Court in Fahy found that the admission of the evidence against the defendant was prejudicial and said that in such a case the question was not whether there was sufficient evidence upon which the defendant could be convicted even without the inadmissible evidence, but rather whether there was a reasonable possibility that the evidence complained of might have contributed to the defendant's conviction. The Court expressly refused to consider the question whether the erroneous admission of evidence obtained by an illegal search and seizure can ever be subject to the harmless error rule. Fahy v. Connecticut, supra at 86 .

42 The information in this paragrapl was taken from Nunes Interview, Oct. 22, 1965.

43 The Alameda County Public Defender Office uses the $\$ 995$ motion, the objection to the evidence at the preliminary examination, and the $\$ \S 1539-40$ motion in such a fashion. 
The district attorneys' biggest problem with the present procedure is not that these motions cause delay, but rather that, except in the case of a section 995 motion and perhaps a section 1539 motion, ${ }^{44}$ there is no appeal available to the prosecution if the defendant's motion is granted. ${ }^{45}$ If the prosecution is by information, the district attorney then has three choices: He can forget about the case; he can refile it and ask another judge to hear the case; or, he can go to the grand jury and seek an indictment. The first choice is undesirable since if there is competent evidence against a person indicating that he might have committed a crime, he should be brought to trial in the interests of society. The second alternative is not very practical because one mumicipal court judge ordinarily will not overrule his counterpart in the same court. ${ }^{46}$ The third alternative is time consuming and expensive; it does not solve the issue of admissibility of the evidence, but only postpones it until the defendant challenges the evidence again in the superior court. It is true that if the defendant chooses to make a section 995 motion in the superior court, the district attorney could appeal an adverse ruhing. ${ }^{47}$ But obtaining such an appeal by having to go through the indictment process is both burdensome and circuitous. Prosecutors generally feel that they should be allowed to appeal from all preliminary rulings. on these motions. They believe that there are many cases where the search and seizure is justified, but a judge will hold otherwise and the prosecution will be ruled out of court. ${ }^{48}$

Many defense attorneys, however, feel that although the present law could be simplified, the section 995 motion to set aside the accusatory pleading should be retained since it is easily made and in effect constitutes an appeal for the defendant from a municipal court determination. ${ }^{49}$ At

Nunes Interview, Oct. 22, 1965. In some instances it is possible that the bargaining effectiveness of the various motions is not appreciably great. This can be the case where a particular district attorney office tries to screen out questionable cases beforehand, but there is no guarantee that a judge will agree that even such a screened search and seizure was legal.

44 See note 23 supra.

45 See note 17 supra.

46 Hederman Interview, Oct. 29, 1965.

47 See note 32 supra.

48 Hederman Interview, Oct. 29, 1965.

49 Nunes Interview, Oct. 29, 1965; Perasso Interview, Oct. 29, 1965. The Alameda County Public Defender's Office has had much success with this motion. At times that office will make it for tactical reasons even when it is obvious that the motion will be demed because it often indicates to the judge that the case against the defendant is weak. If this is so, the prosecution will sometimes be asked or encouraged by the court to reduce or dismiss the charge against the defendant. Although it is possible to apply for a writ of prohibition if the motion is demied, the Alameda office says that it does not usually apply for the writ because such applications are rarely granted by the appellate courts. Nunes Interview, Oct. 22, 1965. The San Francisco Public Defender's Office also makes heavy use of the \& 995 motion. In the twelve-month period from July 1964 to July 1965, the San Francisco office made 209 motions under $\$ 995$. Of these, 55 were granted, 146 demed, and 8 withdrawn. San Francrsco Pubitc DEFENDER, ANNUAI REPORT 9 (1964-65). In fact, in most large cities with a large volume of 
present the prosecution has no similar means by which it can appeal from an order granting the defendant's motion in the municipal or justice court, ${ }^{50}$ and if there is not enough other evidence the case will be dismissed.

It seems desirable to provide for an appeal from an adverse ruling on any preliminary motion so that a prosecution will not fail on an error of law by a single lower court judge. A more streamlimed procedure for challenging searclies and seizures would also be desirable. However, since a constitutional riglt is involved, this streamlining should only be done in such a manner that the opportunities to the defendant to enforce his constitutional rights will be preserved.

\section{II}

THE PROPOSED CAIIFORNIA LAW

A bill that would streamline the present procedure by providing for a single pretrial motion to challenge a search and seizure was introduced in the 1965 general session of the California Legislature. ${ }^{51}$ The pretrial

cases, the $\$ 995$ motion is probably the earliest test of a search and seizure that can be made as a practical matter. This is because the public defender in a large city often will not know much about the defendant's case until the preliminary examination, and will not be able to make an effective and knowledgeable motion until after the preliminary examination. This is not usually true in the case of a private defense attorney who is able to become wellacquainted with a case before the date set for the preliminary examination. Mr. Perasso indicated that the $\& 995$ motion does not put too great a burden on his staff since that motion is usually decided by the judge from the transcript on oral motion, although occasionally a judge will ask for a memorandum of points and authorities. If the $\$ 995$ motion is denied, the San Francisco office also does not usually apply for a writ of prohibition, mainly because of a lack of staff to handle these applications. Sometimes that office will not raise the search and seizure issue at all prior to trial for the reason that if the motion is granted at trial and the defendant is acquitted, the prosecution cannot appeal. This is the result of the rule expressed in two cases: People v. Berger, 44 Cal. 2d 459, 282 P.2d 509 (1955), allows a defendant to raise the issue of admissibility of the evidence at trial whether or not he has raised it before; People v. Valenti, 49 Cal. 2d 199, 316 P.2d 633 (1957), held that once the defendant has been placed in jeopardy by the start of a trial, an acquittal may not be appealed by the State even on a claimed error of law. The San Francisco office also uses the various inotions for bargaining purposes in close cases. Tf the search and seizure was not clearly good, the defendant can say it was clearly bad and then bargain with the prosecution for not bringing up the issue. Perasso Interview, Oct. 29, 1965.

50 See note 17 supra.

51 The bill was Assembly Bill 1651 introduced in the 1965 regular session by Assemblyman Deukmejian on March 8, 1965. It was eventually referred to the Criminal Procedure Committee for interim study during the 1965-67 interim. The bill deals with procedures for challenging the legality of a search and seizure in a criminal case, and presumably would not affect the right of a person to bring a civil action to recover the property. See note 27 supra and accompanying text. A.B. 1651 is reprinted below as it was amended and referred for interim study:

The people of the State of California do enact as follows: SECTION 1. Section 1538.5 is added to the Penal Code to read: 1538.5 (a) A defendant aggrieved by an unreasonable search or seizure con- 
ducted by a government agent may move for the return of property or to suppress as evidence anything so obtained on the ground that:

(1) The search and seizure without a warrant was unreasonable; or

(2) The search and seizure with a warrant was unreasonable because the warrant is insufficient on its face; the evidence seized is not that described in the warrant; there was not probable cause for the issuance of the warrant; or the method of execution of the warrant violated federal or state constitutional standards.

(b) The motion shall be in writing and state facts showing wherein the search and seizure was unreasonable. When possible, the motion should be heard by the magistrate who issued the search warrant if there is a warrant. The judge or magistrate shall receive evidence on any issue of fact necessary to determine the motion. The burden of proving that the search and seizure was unreasonable shall be on the defendant if the search is by warrant and the burden of proving that the search and seizure was reasonable shall be on the people where the search is without warrant. If the motion is granted, the property shall be restored, unless otherwise subject to lawful detention, and it shall not be admissible in evidence against the movant at any trial. Such return shall not be made until available appellate remedies have been exhausted or the time for such proceedings has passed.

(c) If the property seized relates to a felony offense initiated by a complaint, the motion shall be made in the nunicipal or justice court before preliminary hearing except that if opportunity for this motion did not exist or the defendant was not aware of the grounds for the motion prior to preliminary hearing, the defendant shall have the right to make this motion for the first time during the course of trial. If the property seized relates to a felony offense initiated by an imdictment, the motion shall be made in the superior court before trial except that if opportunity for this motion did not exist or the defendant was not aware of the grounds for the motion prior to trial, the defendant shall have the right to make this motion for the first time during the course of trial. If the property seized relates to a misdemeanor offense, the motion shall be made in the mumcipal or justice court before trial except that if opportunity for this motion did not exist or the defendant was not aware of the grounds for the motion prior to trial, the defendant shall have the right to make this motion for the first time during the course of trial.

(d) If the property seized relates to a felony offense initiated by a complaint or to a misdemeanor offense and the defendant made a motion for the return of the property or its suppression as evidence in the nunicipal or justice court prior to preliminary hearing or misdemeanor trial, both the people and the defendant shall have the right to appeal any decision of that court to the superior court of the county in which such inferior court is located, in accordance with the Cabfornia Rules of Court provisions governing appeals from municipal and justice courts in criminal cases. If the property seized relates to a felony offense initiated by an indictment and the defendant made a motion for the return of property or its suppression as evidence in the superior court prior to trial, both the people and the defendant shall have the right to appeal any decision of that court to the appellate courts of Cakfornia by means of an extraordinary writ of mandate or prohibition.

(e) All proceedings in a criminal case relating to the material seized shall be stayed pending the termination of these proceedings and of any appeal therefrom.

(f) These proceedings shall constitute the sole and exclusive remedy to test the validity of a search and seizure in a criminal case, and further review can be had only on an appeal from a conviction in the criminal case.

(g) Nothing contamed in this section is applicable to, or shall prohibit a person from making, a motion to return property brought on the ground that the property held in the possession of a governnient agent is not obscene as defined in Penal Code Section 311 .

SECTION 2. Section 1539 of said code is amended to read: 1539. If a hearing 
procedure outlined in the proposed bill is similar to that presently used in the Federal courts. ${ }^{52}$

The bill, A.B. 1651, provides that a defendant must make a pretrial motion prior to the preliminary learing if the prosecution was by complaint or prior to trial if the prosecution was by indictment, or else he waives the right to object at trial to the admission of the evidence obtained by the search and seizure. There are, however, two exceptions to this rule of waiver. The defendant may raise the issue for the first time at trial if: (1) opportunity for the motion did not exist, or (2) the defendant was not aware of the grounds for the motion prior to the time he was supposed to make it. The bill also authorizes an appeal for both the People and the defendant from a ruling on the pretrial motion.

\section{A. The Federal Procedure}

Originally the federal courts required a pretrial motion under the rule of Weeks v. United States. ${ }^{53}$ The courts proceeded to engraft some exceptions to the rule, and a pretrial motion was not required where the defendant was unaware until the trial that evidence had been seized from him; or where the unlawfulness of the seizure was not disputed or was patent when the evidence was offered at trial. ${ }^{54}$

be held pursuant to section 1538.5, the judge or magistrate must proceed to take testimony in relation thereto, and the testimony of each witness must be reduced to writing and authenticated in the manner prescribed in Section 869.

62 FED. R. CRTM. P. 4I (e). That section reads as follows:

41(e). Motion for Return of Property and to Suppress Evidence.

A person aggrieved by an unlawful search and scizure may move the District Court for the district in which the property was seized for the return of the property and to suppress for the use as evidence anything so obtained on the ground that (1) the property was illegally seized without warrant, or (2) the warrant is insuffcient on its face, or (3) the property seized is not that described in the warrant, or (4) there was not probable cause for believing the existence of the grounds on which the warrant was issued, or (5) the warrant was illegally executed. The judge shall receive evidence on any issue of fact necessary to the decision of the motion. If the motion is granted the property shall be restored unless otherwise subject to lawful detention and it shall not be admissible in evidence at any hearing or trial. The motion to suppress evidence may also be made in the district where the trial is to be had. The motion shall be made before trial or hearing unless opportunity therefor did not exist or the defendant was not aware of the grounds for the motion, but the court in its discretion may entertain the motion at the trial or hearing.

53232 U.S. 383 (1914).

54 Note, 1 U. CEI. L. REv. 120, 122-23 (1933). This Note also gives a good summary of the arguments for and against an exclusive pretrial procedure. In favor of an optional rule it is said that although a delay may be caused in setting the issue, the defendant does not lose his chance to challenge the evidence in those cases where he was unaware until the trial that it was going to be used against him. The prosecution, on the other hand, should be prepared to defend any attack on its evidence whether made before or at trial. In addition, in many cases the evidence that the defendant challenges by a pretrial motion might never be used 
More importantly, however, the trial judge had discretion to decide that the defendant could raise the issue for the first time at trial. In Nardone $v$. United States ${ }^{55}$ the Court considered the argument that speed in the trial of criminal cases was essential to combat crime, and that a preliminary procedure would ensure this speed and would also prevent the interruption of the trial and the consequent breaking of its momentum and the continuity of the jury's attention. The Court recognized, however, that in some cases the defendant might not have been able to present his challenge at an earlier time for a legitimate reason. It concluded that the system must rely on the wise discretion of the trial judge in determining whether to allow the defendant to raise the issue for the first time at trial. ${ }^{56}$ When Rule 41(e) was adopted in 1948, a provision permitting trial court discretion was expressly included. In addition, the defendant may always raise the motion for the first time at trial if opportunity for the motion did not exist or he was not aware of the grounds for the motion before trial. ${ }^{57}$ Rule 41 (e) was not, therefore, a break with the former law but a continuation of it. $^{58}$

\section{B. Problems With A.B. 1651}

In the federal courts the defendant is offered a flexible and relatively simple procedure to enforce his rights, and a similar procedure in California would be desirable. A.B. 1651; however, fails to provide for trial court discretion to entertain the motion for the first time at trial. It also raises certain problems of interpretation and some practical difficulties for both prosecutors and defense attorneys that make its passage undesirable.

at trial. In such a case the judge's time spent in conducting a prior inquiry to determine the admissibility of the evidence will have been wasted. $I d$. at 121 . On the other hand, the argument for the exclusive pretrial procedure is based upon the desire to force the defendant to use it in the belief that such a motion is the best method to handle a search and seizure issue. The argument continues that if the defendant is not forced to object prior to trial, the prosecution will not usually be aware that the defendant will seek to challenge the evidence and will not be prepared to defend the point. Typically, trials are handled by deputies remote from the knowledge of how the evidence was obtained. Id. at 122. This is the case in many California district attorney offices, at least when the prosecution is by infornation, for a different deputy usually takes over the case once it reaches the superior court. Hederman Interview, Oct. 29, 1965.

55308 U.S. 338 (1939).

56 Id. at 342 .

67 See note 53 supra.

58 The Advisory Committee explicitly states this in its notes to Rule 41 . Notes of Advisory Committee on Rules, 18 U.S.C.A. $\$ 41$ (1961). In Jones v. Umited States, 362 U.S. 257 (1960), the Court emphasized that Rule 41 (e) is not rigid, and that the discretion left in the trial judge proves that an important social policy, and not a "narrow, finicky procedural requirement," is involved. Id. at 264. 


\section{Trial Court Discretion}

The proposed bill allows the trial court to entertain the motion to suppress for the first time at trial only if opportunity for the pretrial motion did not exist or if the defendant was unaware of the grounds for making it. ${ }^{59}$ Rule 41 (e) on the other hand, besides expressly permitting the trial court to entertain the motion for those two reasons, also grants the court discretion to entertain the motion in any case for the first time at trial. ${ }^{60}$

Under Rule 41(e) the trial court's discretion is absolute for all practical purposes. Apparently it has discretion to permit the motion for the first time at trial even though orderly procedure would require that the motion be made before the trial. ${ }^{61}$ And the grant of discretion is not limited to cases where the defendant was not aware of the grounds for the motion or where opportunity for the motion did not exist before trial. ${ }^{02}$ A discretionary power should be given to trial judges in California im order to fully protect the defendant in cases where for some excusable reason he has not raised the issue earlier: for example, if new evidence at the trial, or the testimony of a witness, casts doubt upon the legality of a search and seizure previously thought legal.

If discretion is not given to the trial court, the defendant will be able to make the motion for the first time at trial only if he meets the two specific exceptions. Thus, he will always have the burden of convincing the judge that he was not aware of the grounds for the motion or that opportunity to make it did not exist. It is doubtful that any defense attorney would want this burden under the proposed statute as it now reads since the language of the two exceptions does not leave much room for judges to take practical problems of a defense attorney into account..$^{.3}$ A discretionary provision, however, would allow them to take notice of these practical problems.

The dissenting opinion in People v. Peterson ${ }^{64}$ makes an interesting observation on the relation of Rule 41(e) to the California rule on waiver under sections 1539 and 1540. The United States Supreme Court has held that the fourth amendment prohibition against unreasonable searches and seizures and the exclusionary evidence rule apply in the state courts. ${ }^{05}$

\footnotetext{
58 A.B. 1651, \& (c), supra note 51 .

60 See note 52 supra.

61 Gallegos v. United States, 237 F.2d 694, 697 (10th Cir. 1956).

62 Giacona v. United States, 257 F.2d 450 (5th Cir. 1958).

${ }^{63} \mathrm{Mr}$. Perasso expressly stated he did not think that judges would take judicial notice of the volume of cases that a public defender office handles if they had before them only the language of the two exceptions. Perasso Interview, Oct. 29, 1965.

64233 Cal. App. 2d 481, 499, 43 Cal. Rptr. 457, 468 (1965).

65 Ker v. California, 374 U.S. 23 (1963); Mapp v. Ohio, 367 U.S. 643 (1961).
} 
The dissenting judge in Peterson indicated that in his opinion the Supreme Court will follow the procedure outlined in Rule 41 (e) as the minimum procedure necessary to protect a defendant's constitutional rights. ${ }^{66}$ In fact, the majority opinion in Peterson attempted to provide for a himited discretion in the trial court to entertain a section 1539-1540 motion for the first time at trial in those cases where the motion had been raised properly at a reasonable time before the trial and yet the magistrate had wrongfully refused to conduct the hearing. In that case, says the court, the "trial court still will be vested with a broad discretion to determine the reasonable disposition that should be nade with respect to any tardy or inappropriate assertion of the right." that the trial judge also might have conducted such a hearing with appellants' consent or made some other order appropriate in the premises." The dissent's reasoning is not necessarily correct: A procedure might well be constitutional and yet afford the defendant less of an opportunity to challenge the admissibility of evidence than that afforded by the Federal Rules. Yet, the Rules might be a good guide as to how the Supreme Court will feel about a certain subject, especially when the waiver of a constitutional right is involved. Although it is unlikely, it is still conceivable that a discretionary power given to the trial court would be necessary for a statute to pass constitutional scrutiny.

The only danger with a discretionary provision is that the motion will be purposely withheld by the defendant until trial, the defendant will be acquitted; and the prosecution will not be able to appeal. This danger, however, could be greatly limited by providing a guideline in the statute for the judge's discretion. The proposal might read as below; ${ }^{69}$ adding the words in italics to the text of A.B. 1651:

(e) But in any case under this section the trial court must entertain the motion for the first time at trial:

(1) if it appears that opportunity for the motion did not exist or the defendant was not aware of the grounds for the motion at the preliminary examination if a felony offense where prosecution is imitiated by a complaint, or prior to the trial if the prosecution is by indictment or if the offense is a misdemeanor; or

(2) if, in the exercise of sound judicial discretion, taking account of the interests of justice to the defendant and the orderly administration of criminal procedure, the trial court finds that the defendant's failure to make the motion earlier is excusable.

68233 Cal. App. at 508, 43 Cal. Rptr. at 473.

67 Id. at 496, 43 Cal. Rptr. at 466.

68 Id. at 49 \%, 43 Cal. Rptr. at 466.

09 The various subsections of the proposed draft are lettered from (a) to (h). The entire draft statute is printed in the Appendix to this Comment. 
This draft preserves the two specific exceptions to the waiver rule and adds a discretionary provision. The guideline formulated in the last clause of the subsection is not a limitation on the trial court's discretion, but rather is a statement of what the judge should weigh when determining whether to allow the defendant to make the motion for the first time at trial.

An argument against giving the trial court discretion is that such a provision would increase the number of times the trial would be disrupted by a motion made for the first time at trial. But in most cases the trial would not be significantly disrupted by such a motion any more than any other motion disrupts a trial..$^{70}$ And in any case disruption of the trial would be one factor on the side of the orderly administration of criminal procedure that the judge would consider in the balancing process.

\section{Time and Place for the Motion}

A.B. 1651 provides that if the prosecution is by complaint, the motion to suppress the evidence shall be made prior to the preliminary examination. ${ }^{71}$ In cities where the public defender office is able to handle the daily jail load, and is prepared to raise a search and seizure issue before or at the prehminary examination, this would be feasible. But in other cities such as San Francisco or Los Angeles, the volume of cases is so large and the staff of the public defender so small that counsel's first real acquaintance with the case comes at the preliminary examination. ${ }^{72} \mathrm{~A}$ prepreliminary examination motion in these larger cities would be an impossible burden. A better solution is to provide that the motion shall be made at the preliminary examination, that the judge inust inform the defendant of the procedure available to cliallenge a search and seizure, and that if the defendant indicates that he wisles to challenge the search and seizure, the judge shall order a continuance of the preliminary examination to allow the defendant time to prepare his motion. The provision might read:

70 Hederman Interview, Oct. 29, 1965; Perasson Interview, Oct. 29, 1965; Nunes Interview, Oct. 22, 1965. See also People v. Berger, 44 Cal. 2d 459, 282 P.2d 509 (1955), where the court said: "The issues involved [in the motion to suppress] will ordinarily be no more time consuming or complicated than those presented to the trial court when it must rule, for example, on the admissibility of confessions, busmess records, or evidence claimed to be privileged, or on the qualifications of expert or other witnesses." Id. at 464, 282 P.2d at 512 .

71 A.B. $1651, \S$ (c), supra note 51.

72 Perasso Interview, Oct. 29, 1965. He indicated that usually the deputy will only see the defendant once before the preliminary examination, and will at that time probably recommend a not guilty plea. At the preliminary examination he will concentrate mainly upon how the defendant disagrees with the testimony given at the preliminary examination. In many cases the public defender will not even know until the preliminary examination that there is a warrant or has been a search, and will know only the general nature of the charge against the defendant. 
(c) If the property seized relates to a felony offense where prosecution is initiated by a complaint, the motion shall be made in the municipal or justice court at the preliminary examination. At the preliminary examination the magistrate shall inform the defendant that he may challenge the legality of a search and seizure on any of the grounds set out in subsection (a) of this section. And if the defendant is not then prepared to make a motion under this section, but he indicates a desire to do so, the magistrate shall order a continuance of the preliminary examination to allow the defendant a suitable time to prepare his motion.

(d) If the property seized relates to a felony offense where prosecution is initiated by an imdictment, or to a misdemeanor offense, the motion shall be made in the superior court, or in the justice or municipal court if a misdemeanor offense, before the trial. At the arraignment the judge or magistrate shall inform the defendant that he may, before the trial, challenge the legality of any search and seizure on the grounds set out in subsection (a) of this section.

It would be wise to hear the preliminary motion in conjunction with the preliminary examination since this proceeding affords the first setting for the taking of testimony and introduction of evidence. It would also prevent the splitting up of preliminary procedures which would be cumbersome and time consuming for the prosecution, defense, and judge alike. If the motion were required to be made at the preliminary examination, it would save an extra appearance for the district attorney and the defense attorney, lessen the burden on the court calendar, and put all facts and evidence before the court at the same time.

In People v. Peterson, ${ }^{73}$ the court appeared to say that only an intentional waiver of the defendant's right to challenge a search and seizure would be adequate to waive the section 1539 proceeding. ${ }^{74}$ If this is the California policy, it can be argued that the defendant cannot intentionally

73233 Cal. App. 2d 481, 43 Cal. Rptr. 457 (1965).

74 The court said that it is true that where a defendant fails to use $\$ \$ 1539$ and 1540 he loses the right to question the truth of facts contained in the affidavit upon which the warrant was issued. This is so because even constitutional rights cannot be used to subvert the orderly administration of justice or for dilatory purposes. But such a constitutional right as here involved "necessarily includes the right to utilize all authorized statutory procedures to subject to full and complete examination those legal processes by which society . . . invades the individual's personal right to privacy .... Therefore, absent some showing that such a right has been intentionally waived or is clearly being asserted in an unreasonable effort to thwart efficient and orderly judicial procedure, an appropriate time and place for its exercise must be allowed." People v. Peterson, supra note 73, at 493, 43 Cal. Rptr. at 464. The court went on to say that in the instant case no showing had been made to indicate that the defendant intended to waive his right to a $\S 1539$ hearing when his attorney mistakenly tried to use the preliminary hearing as the procedural device to make such a motion. Such an error by counsel does not indicate an intent to waive this right, but rather an intent to assert it. Id. at 494, $43 \mathrm{Cal}$. Rptr. at 464. 
waive something that he does not know about. ${ }^{75}$ Arguably, the interests of orderly procedure demand that counsel be conclusively presumed to know the procedures available to challenge a search and seizure. However, many attorneys do not actually know what procedures are presently available or how to go about using them. ${ }^{76}$ While a more streamlined procedure would perhaps alleviate this problem to a great extent; the statute should not overlook the possibility that some counsel might fail to use the new prehminary procedure simply because they are iguorant of it or because they forget about it. Every effort should be made to preserve a defendant's constitutional rights, and the proposed draft seeks to accomplish this by requiring the judge to inform the defendant of the available procedure. This is a procedure similar to the one suggested by the court in the Peterson case. ${ }^{77}$ There the court stated that:

Upon learning that a search warrant has been used but that no 15391540 hearing has been held, in an appropriate case the magistrate conducting a preliminary hearing might very properly require the defendant to elect whether to proceed, expressly waiving his right to such a hearing, or to agree that the committing magistrate might himself conduct the 1539-1540 hearing rather than the issuing magistrate, or to agree to a suitable continuance of the preliminary hearing for the purpose of allowing the issuing magistrate to conduct such a hearing. ${ }^{78}$

\section{Who Should Hear the Motion?}

A.B. 1651 provides that "when possible, the motion should be heard by the magistrate who issued the search warrant if there is a warrant."70 Why this procedure should be preferred is not readily apparent. The reasoning appears to be that the issuing magistrate is the person best acquainted with all the relevant facts. On the other hand, since he is also the person who determined in the first place that there was probable cause for the issuance of the warrant, he is unlikely to overrule his earlier decision. In fact, this is one of the prime reasons that defense attorneys often do not use the section 1539 motion to quash the search warrant and infrequently win if they do use it. ${ }^{80}$ If the purpose of providing this procedure is to ensure justice to the defendant, and if the defendant should be encouraged to use the prehminary procedure, it would be better

\footnotetext{
75 See Johnson v. Zerbst, 304 U.S. 458, 464 (1938).

76 Nunes Interview, Oct. 22, 1965.

77 People v. Peterson, 233 Cal. App. 2d 481, 43 Cal. Rptr. 457 (1965).

78 Id. at 495-96, 43 Cal. Rptr. at 465-66. And see the recent case of People v. Butler, 238 A.C.A. 141, 147, 47 Cal. Rptr. 512, 516 (1965), where the court indicates its approval of the suggestion in Peterson.

79 A.B. $1651, \S(\mathrm{b})$, supra note 51.

80 Hederman Interview, Oct. 29, 1965.
} 
to provide that when possible a different judge than the judge who issued the warrant should hear the motion. This would ensure the fullest and most independent review of the earlier decision on probable cause. Thus, the draft would read:

(b) The motion shall be in writing and state facts showing wherein the search and seizure was unreasonable. Where possible, the motion should be heard by a magistrate other than the magistrate who issued the search warrant if there is a warrant.

The purpose of such a provision is to instruct the judges in the municipal or justice courts that if they issued the search warrant upon which the search was based they are to hear the preliminary motion only if it is not practicable for another municipal or justice court judge in the same court to hear it.

\section{Holding the Preliminary Motion Until Trial}

In some cases it might be wise to postpone consideration of the defendant's preliminary motion to suppress until the trial. A.B. 1651 does not explicitly give the judge the power to do this. In the case of a prosecution by information where the motion is to be made in the justice or municipal court before a judge who will not eventually hear the trial, the structure of the proposed bill seems to indicate that such a power could not be implied to the justice or municipal court judge. A provision stating that the justice or municipal court judge could order the motion held over until the trial in the superior court would be useful where the motion might be frivolous or where the judge feels that the factual contentions in the motion can only be fully exposed at the trial. Also, the defendant may be seeking to use the motion solely for dilatory purposes. This last possibility would not be very hikely if a streamlined procedure for challenging searches and seizures were set up as A.B. 1651 and the proposed draft seek to do, whereas under the present law the multitude of motions open to the defendant may encourage dilatory motions. However, it is still possible that a defendant might seek to use a single preliminary motion and a subsequent appeal solely for dilatory purposes, and if it appears that this is what he is doing the judge should have the power to hold the motion over until the trial.

If the magistrate or judge orders the motion held over until trial, no appeal should be allowed. Such an order is not a final judgment and in no way affects the merits of the defendant's contention. The danger of an abuse of discretion is outweighed by the desirability of postponing judgment on motions that cannot be wisely determined until the trial. In addition, the no-appeal provision could work to the defendant's advantage since if the defendant wins his point at trial and is then acquitted, 
the prosecution could not appeal. ${ }^{81}$ This last factor would also discourage the prosecution from indiscriminately claiming that the defendant's motion is frivolous or dilatory, and help to ensure that the prosecution only raises that issue when there are legitimate grounds for so doing. Thus, the statute would read:

(f) If the defendant makes a motion as provided for in subsections (c) or (d), the municipal or justice court magistrate at the preliminary examination or before the trial if the offense is a misdemeanor, or the superior court judge before the trial, may rule on the motion when it is made or may requirc the defendant to postpone his motion until the trial if the magistrate believes that the motion is frivolous, is being made solely for dilatory purposes, or can be fairly determined only after all the relevant facts have been exposed at the trial. If the nagistrate or judge determines that the motion should be postponed until trial, neither the People nor the defendant may appeal that ruling.

\section{The Appeal Procedure}

A.B. 1651 provides that an appeal may be taken by either the People or the defendant to the appellate department of the superior court from a ruling on a pretrial motion in the municipal or justice court. ${ }^{82}$ In many cases a public defender might desire to take an appeal; but would not be able to do so because of the added burden on his staff caused by the formalities of an appeal..$^{83}$ In effect the defendant presently has an appeal from a municipal court ruling by using a section 995 motion in the superior court which is in most cases determined from the transcript on oral motion, with perhaps an occasional judge asking for a memorandum of points and authorities. ${ }^{84}$ An ordinary appeal requires written briefs and is more formal and more difficult to present than a section 995 motion. The section 995 motion, however, is not now available to the prosecution as an appeal. Althougli an informal appeal would probably be preferable to both prosecutors and defense attorneys alike, many district attorneys would most likely prefer an appeal to the appellate department rather than an appeal to one superior court judge under a proceedimg similar to a section 995 motion. ${ }^{85} \mathrm{~A}$ review can better be made by a real appellate

81 See note 49 supra.

82 A.B. 1651 , \& (d), supra note 51.

83 Perasso Interview, Oct. 29, 1965.

84 Nunes Interview, Nov. 29, 1965. Mr. Nunes said that in most counties the present $\S 995$ motion is quite informal, but that recently in Alameda County there has been a trend toward submitting fairly detailed memorandums of points and authorities.

85 Hederman Interview, Oct. 29, 1965. One possibility would be to provide that the prosecution may appeal to the appellate department of the superior court, but that the defendant may either appeal to the appellate department or use the present $\$ 995$ motion as his appeal. Such a provision for an alternative appeal, however, would allow a defendant to pick a more 
court. $^{88}$ One superior court judge might hesitate to overrule a municipal court judge. However, this does not mean that an appeal would have to be formal, and the draft seeks to provide for an informal appeal.

A.B. 1651 also provides that either the People or the defendant may appeal from a ruling on a preliminary motion. ${ }^{87}$ It says further that "These proceedings shall constitute the sole and exclusive remedy to test the validity of a search and seizure in a criminal case, and further review can be had only on an appeal from a conviction in the criminal case." ${ }^{88}$ The bill does not explicitly indicate if a ruling on a preliminary appeal is binding on the defendant. Nor does the bill explicitly state whether a prehminary appeal is optional for the defendant. If it were considered to be optional, the quoted language could be interpreted to mean that a ruling on a preliminary appeal is a final determination if an appeal is taken; but that if no appeal is taken, the defendant can raise the issue again in an appeal from a conviction. Most likely, however, the provision means that even if an earlier appeal is taken the defendant will be entitled to further review of the issue of admissibility if he appeals from a judgment of conviction. This seems to be the most natural reading of the provision, and would ensure the defendant the maximum review of the merits of his motion and the fullest protection of his constitutional rights. ${ }^{89}$ It would not deprive the prosecution of its riglit to appeal, but

favorable court when this same option is not available to the prosecution. In addition, it would detract from the streamlining of the law that the statute is trying to accomplish. Mr. Hederman suggested the possibility of creating an appellate department of the municipal court in the larger cities where the number of judges in the nunicipal court is sufficient. Such a department could relieve the appellate department of the superior court from any added burden brought on it by a provision allowing an appeal to then. The only practical problem with this proposal is the fact that nunicipal court judges on the appellate department might be good friends with the nunicipal court judge who made the decision and therefore be even more hesitant to overrule him. Yet, the suggestion might be a possible solution to the problem of the added burden that would be thrown upon the appellate department of the superior court.

${ }^{88}$ This is also Mr. Hederman's position. Hederman. Interview, Oct. 29, 1965. Some defense attorneys, bowever, will not take an appeal to the appellate department because the tendency of some appellate departments is to be conservative and not offer much hope for a defendant aggrieved by an adverse ruling. Nunes Interview, Nov. 29, 1965. The fear of conservatism in the appellate departments might be ill-founded as a general proposition. In any case the defendant would ultimately be protected fron this conservatisn by his right to appeal from an appellate department decision.

87 A.B. 1651, \& (d), suprct note 51 .

88 A.B. 1651 , \& (f), supra note 51.

${ }^{89}$ In fact, the opposite interpretation which would make a preliminary appellate decision binding on the defendant might raise an issue respecting the preservation of a federal question for appeal if the defendant sought an appeal to the United States Supreme Court. This issue is beyond the scope of this Comment, but points out an additional consideration militating against such an interpretation of the proposed bill. 
the effect of the preliminary appeal if the prosecution was successful would only be to ensure that the case goes to trial and that the evidence will be admitted at the trial. It would be better, however, if the exact meaning of the provision were spelled out clearly in the statute so as to eliminate any possible doubts.

Further, the trial judge slould be able to rule on the merits of the motion if the defendant makes it again at trial and new facts have appeared that were not available or presented to the appellate court at the time of the appeal. This would assure a maximum of flexibility in the preliminary procedure and a fuller protection of the defendant's riglits.

As indicated above it is unclear whether the proposed bill sets up an optional appeal procedure. The bill provides that both the People or the defendant "shall have the right to appeal" a ruling on a preliminary motion,${ }^{90}$ but it is not indicated if the appeal is optional or if the defendant will instead waive lis right to object at trial to the admission of the evidence if he does not appeal. The proposed draft provides for an optional appeal since even thougl appellate review of a preliminary decision is desirable, it is of ten not practical for a defendant to take an independent appeal of the issue. ${ }^{91}$ Under an optional appeal procedure; the prosecution's right to appeal a preliminary decision instead of getting ruled out of court would still be guaranteed. If the defendant does not appeal a preliminary decision, the draft provides that he may urge error on appeal from a judgment of conviction as long as he objects to the evidence at the trial. If lie objects, the trial judge must rule on the merits of the motion. By objecting the defendant imdicates a desire to preserve the issue for appeal, and also ensures that the record of the preliminary motion goes up on appeal. ${ }^{92}$ If lie does not object at trial, lie waives the issue. It slould not be left open for a California court to liold that a prehiminary ruling that was not appealed is binding on the trial court when the defendant objects to the evidence at the trial..$^{93}$ The proposed draft

90 A.B. $1651, \&$ (d), suppra note 51 .

91 This would be the case in a large city where the public defender office liandles a heavy number of cases and does not have a large enough staff to prosecute appeals. Perasso Interview, Oct. 29,1965 . In addition, in all cases there is the factor that the expenses of an appeal might be too great for some defendants.

82 See note 40 supra.

93 This is what the court held in United States v. Gatewood, 109 F. Supp. 440 (D.D.C.), rev'd on other grounds, 209 F.2d 789 (D.C. Cir. 1953). It said that a pretrial ruling on a motion to suppress becomes the law of the case and cannot be reconsidered on its merits during the trial. The case went up on appeal, but the issue of whether the trial court's ruling on a preliminary motion would bind it at trial was not necessary to a decision. The appellate court, however, indicated that were it necessary to a decision they would hold that such a ruling would not bind the trial court. This is the traditional position of the federal courts under the case of Gouled v. United States, 255 U.S. 298, 312-13 (1921). In Gouled it was leld that, at least in the case where it becomes probable that there has been an unconstitu- 
also seeks to eliminate this possibility. Thus, the appeal provisions would read:

(g) Appellate review

(1) If the property seized relates to a felony offense where prosecution is imitiated by a complaint or to a misdemeanor offense and the defendant made a motion for the return of the property or its suppression as evidence in the municipal or justice court at the preliminary hearing or prior to a misdemeanor trial, both the People and the defendant shall have the right to appeal any decision of that court to the superior court of the county in which such inferior court is located, and from there to the appellate courts of California in accordance with the Cahifornia Rules of Court provisions governing appeals from municipal and justice courts in criminal cases. ${ }^{94}$ In the case of a felony offense where prosecution is initiated by indictment, if the defendant made a motion for the return of property or its suppression as evidence in the superior court prior to trial, both the People and the defendant shall have the right to appeal any decision of that court to the appellate courts of California by means of an extraordinary writ of mandate or prohibition.

(2) The appeal provided in (1) above is not mandatory and if the defendant does not take an appeal, he may preserve his right to raise the issue on appeal from a judgment of conviction by objecting to the admission of the evidence that was the subject of his pretrial motion when that evidence is sought to be introduced at the trial, and the trial judge shall determine the motion on its merits. If an appeal it taken, and the appellate court's judgment is in favor of the prosecution, the ruling is not final and the defendant may urge error on an appeal from a judgment of conviction. The trial judge, however, may rule on an objection made at the trial to the admission of the same evidence that was the subject of the pretrial motion only if at the trial new facts regarding the search and seizure appear which were not presented or available to the appellate court in the earlier appeal.

(3) If an appeal is taken to the appellate department of the superior court under (1) above, the procedure for and presentation at such an appeal shall be as informal as possible while still ensuring a full and comprehensive review of the municipal or justice court's determination. Written briefs or memorandums of points and authorities may be required at the option of the individual appellate department.

tional search and seizure, the ruling on the pretrial motion to suppress does not excuse the trial court from its duty to entertain a motion at the trial and to decide it as then presented. 04 At present in a misdemeanor case the defendant has no appeal under Penal Code $\$ 1466$ from an order denying a motion to quash but may seek an extraordinary writ to obtain relief under the rule of Dunn v. Municipal Court, 220 Cal. App. 2d 858, 34 Cal. Rptr. 251 (1963). See note 22 supra. As in the case of a felony prosecution, there is no appeal from a denial of a preliminary motion to suppress and the defendant must renew his objection at trial to preserve the issue for appeal from a judgment of conviction under the rule of People v. Justice Court, 185 Cal. App. 2d 256, 8 Cal. Rptr. 176 (1960). See note 40 supra. For the procedure governing appeals from the municipal court to the appellate department of the superior court see CAI. RULES OF CoURT 182-91. 


\section{CONCLUSTON}

The proposed draft ${ }^{95}$ ensures to the defendant adequate protection of his constitutional rights, and to the prosecution full opportunity to appeal a preliminary decision and adequate safeguards against dilatory motions. The present Cahifornia law is confusing and unnecessarily repetitive, but it does have the advantage that the defendant has many opportunities to assert his constitutional rights. The proposed bill, A.B. 1651, provides a streamlined procedure, but fails to take into account the practical problems of defense attorneys and fails to provide the fullest possible measure of protection for the defendant's rights, most notably by not providing for trial court discretion to entertain the defendant's motion for the first time at trial. The draft endeavors to cure the faults of the present law and the proposed bill and yet retain the opportunities that the present law provides for the protection of the defendant's rights. It will perhaps at least present a starting point for future legislation, and be of some assistance in drafting a law that will adequately protect the interests of both the prosecution and the defendant.

\section{Carl J. Seneker II}

\section{APPENDIX}

The people of the State of California do enact as follows:

SECTION 1. Section 1538.5 is added to the Penal Code to read:

1538.5. (a) A defendant aggrieved by an unreasonable search or seizure conducted by a government agent may move for the return of property or to suppress as evidence anything so obtained on the ground that:

(1) The search and seizure without a warrant was unreasonable; or

(2) The search and seizure with a warrant was unreasonable because the warrant is insufficient on its face; the evidence seized is not that described in the warrant; there was not probable cause for the issuance of the warrant; or the method of execution of the warrant violated federal or state constitutional standards.

(b) The motion shall be in writing and state facts slowing wherein the search and seizure was unreasonable. Where possible, the motion should be. heard by a magistrate other than the magistrate who issued the search warrant if there is a warrant. The judge or magistrate shall receive evidence on any issue of fact necessary to determine the motion. The burden of proving that the search and seizure was unreasonable shall be on the defendant if the search is by warrant and the burden of proving that the search and seizure was reasonable shall be on the people where the search is without a warrant. If the motion is granted, the property shall be restored, unless otherwise subject to

95 The proposed draft is printed in its entirety in the Appendix to this Comment. A.B. 1651, printed in note 51 supra, has some substantive provisions. This Comment, however, is not meant to deal with these issues or express any opinion on them. Those sections not dealing with procedure are reproduced in the proposed draft in the Appendix to improve the readability of the text. 
lawful detention, and it shall not be admissible in evidence against the movant at any trial. Such return shall not be made until available appellate remedies have been exhausted or the time for such proceedings has passed.

(c) If the property seized relates to a felony offense where prosecution is initiated by a complaint, the motion shall be made in the municipal or justice court at the preliminary examination. At the preliminary examination the magistrate shall inform the defendant that he may challenge the legality of a search and seizure on any of the grounds set out in subsection (a) of this section. And if the defendant is not then prepared to make a motion under this section, but he indicates a desire to do so, the magistrate shall order a continuance of the preliminary examination to allow the defendant a suitable time to prepare his motion.

(d) If the property seized relates to a felony offense where prosecution is mitiated by an imdictment, or to a misdemeanor offense, the motion shall be made in the superior court, or in the justice or municipal court if a misdemeanor offense, before the trial. At the arraignment the judge or magistrate shall inform the defendant that he may, before the trial, challenge the legality of any search and seizure on the grounds set out in subsection (a) of this section.

(e) But in any case under this section the trial court must entertain the motion for the first time at trial:

(1) if it appears that opportunity for the motion did not exist or the defendant was not aware of the grounds for the inotion at the preliminary examination if a felony offense where prosecution is initiated by a complaint, or prior to the trial if the prosecution is by indictment or if the offense is a misdemeanor; or

(2) if, in the exercise of sound judicial discretion, taking account of the interests of justice to the defendant and the orderly administration of criminal procedure, the trial court finds that the defendant's failure to make the motion earlier is excusable.

(f) If the defendant makes a motion as provided for in subsections (c) or (d), the municipal or justice court magistrate at the preliminary examination or before the trial if the offense is a misdemeanor, or the superior court judge before the trial, may rule on the motion when it is made or may reqnire the defendant to postpone his motion until the trial if the magistrate believes that the motion is frivolous, is bemg made solely for dilatory purposes, or can be fairly determined only after all the relevant facts have been exposed at the trial. If the magistrate or judge determines that the motion should be postponed until trial, neither the People nor the defendant may appeal that ruling.

(g) Appellate review

(1) If the property seized relates to a felony offense where prosecution is initiated by a complaint or to a misdemeanor offense and the defendant made a motion for the return of the property or its suppression as evidence in the municipal or justice court at the preliminary hearing or prior to a misdemeanor trial, both the People and the defendant shall have the right to appeal any decision of that court to the superior court of the county in which such inferior court is located, and from there to the appellate courts of California, in accordance with the California Rules of Court provisions governing appeals from municipal and justice courts in criminal cases. In the case of a felony offense where prosecution is initiated by indictment, if the defendant made a motion for 
the return of property or its suppression as evidence in the superior court prior to trial, both the People and the defendant shall have the right to appeal any decision of that court to the appellate courts of California by means of an extraordinary writ of mandate or prohibition.

(2) The appeal provided in (1) above is not mandatory and if the defendant does not take an appeal, he may preserve his right to raise the issue on appeal from a judgment of conviction by objecting to the admission of the evidence that was the subject of his pretrial motion when that evidence is sought to be introduced at the trial and the trial judge shall determine the motion on its inerits. If an appeal is taken, and the appellate court's judgment is in favor of the prosecution, the ruling is not final and the defendant may urge error on an appeal from a judgment of conviction. The trial judge, however, may rule on an objection made at the trial to the admission of the same evidence that was the subject of the pretrial motion only if at the trial new facts regarding the search and seizure appear which were not presented or available to the appellate court in the earher appeal.

(3) If an appeal is taken to the appellate department of the superior court under (1) above, the procedure for and presentation at such an appeal shall be as informal as possible while still ensuring a full and comprehensive review of the inunicipal or justice court's determination. Written briefs or memorandums of points and authorities may be required at the option of the individual appellate department.

(h) These proceedings shall constitute the sole and exclusive remedy to test the validity of a search and seizure in a criminal case. All proceedings in a criminal case relating to the material seized shall be stayed pending the termination of these proceedings and of any appeal therefrom.

SECTION 2. Section 1539 of said code is amended to read:

1539. If a hearing be held pursuant to Section 1538.5 , the judge or magistrate must proceed to take testimony in relation thereto, and the testimony of each witness must be reduced to writing and authenticated in the manner prescribed in Section 869. 